\title{
Replication Timing of DNA Sequences Associated with Human Centromeres and Telomeres
}

\author{
KELLY G. TEN HAGEN, ${ }^{1}$ DAVID M. GILBERT, ${ }^{1} \dagger$ HUNTINGTON F. WILLARD,${ }^{1}$ AND \\ STANLEY N. COHEN ${ }^{1,2 *}$ \\ Departments of Genetics ${ }^{1}$ and Medicine, ${ }^{2}$ Stanford University School of Medicine, \\ Stanford, California $94305-5120$
}

Received 21 May 1990/Accepted 13 September 1990

\begin{abstract}
The timing of replication of centromere-associated human alpha satellite DNA from chromosomes X, 17, and 7 as well as of human telomeric sequences was determined by using density-labeling methods and fluorescenceactivated cell sorting. Alpha satellite sequences replicated late in $\mathbf{S}$ phase; however, the alpha satellite sequences of the three chromosomes studied replicated at slightly different times. Human telomeres were found to replicate throughout most of $S$ phase. These results are consistent with a model in which multiple initiations of replication occur at a characteristic time within the alpha satellite repeats of a particular chromosome, while the replication timing of telomeric sequences is determined by either telomeric origins that can initiate at different times during $S$ phase or by replication origins within the flanking chromosomal DNA sequences.
\end{abstract}

Replication of DNA in eucaryotic cells has been shown to proceed nonrandomly according to a specific temporal order (reviewed in references 19 and 21). Each chromosomal DNA segment, and presumably each single-copy gene, is replicated at a particular time in $\mathrm{S}$ phase of the cell cycle, and this temporal order of replication is maintained from one cell cycle to the next $(1,29,33)$. Short repetitive sequences such as members of the Alu family, which are present in multiple copies dispersed on different chromosomes, appear to have no unique replication time but instead are replicated throughout $S$ phase (15); potentially, this replication pattern may result from the presence of origins of replication within Alu sequences that can fire throughout $S$ phase or, alternatively, from the collective effects of replication initiated within the flanking chromosomal DNA segments.

Telomeres and centromeres are genetically important structural elements present on each eucaryotic chromosome. Telomeres consist of apparently identical repeat sequences that define the ends of chromosomes (reviewed in reference 43). The telomeric sequences isolated from human cells are preferentially sensitive to $\mathrm{Ba} / 31$ nuclease digestion (28), hybridize in situ to the ends of all human chromosomes (28), and appear to mediate telomere formation in yeast cells $(6,9)$. Centromeres accomplish the distribution of sister chromatids to daughter cells at the time of division (reviewed in reference 8). Both cytological and cell biological studies suggest that alpha satellite sequences, which consist of multiple copies of a tandemly repeated 171-bp motif present in long contiguous arrays in the centromeric region of each chromosome (reviewed in reference 42 ), may be a DNA component of human centromeres (40a); in situ and biochemical studies show that a major centromere protein binds specifically a 17-bp motif of alpha satellite DNA and furthermore colocalizes with alpha satellite at the centromere throughout the cell cycle $(24,25,31)$.

It previously has been reported that both centromeres and

\footnotetext{
* Corresponding author.

$\dagger$ Present address: Centre National de la Recherche Scientifique 11, 67085 Strasbourg, France.
}

telomeres, unlike certain other eucaryotic DNA sequences present on chromosomes in multiple copies, replicate at specific times in $\mathrm{S}$ phase. Certain cytogenetic studies suggesting that the heterochromatic centromeric regions of eucaryotic cells replicate late in $S$ phase $(10,22,33,34)$ have led to the proposal that the late replication timing of centromeres could ensure that sister chromatids are held together until anaphase of the cell cycle $(12,30,35)$. However, more recent investigations in yeast cells using density gradient methods have indicated that the replication of centromeres occurs early (26). While the sequences adjacent to some yeast telomeres have been found to replicate late during $S$ phase (26), it is unclear whether this replication timing is an inherent property of these sequences or instead is a reflection of their distance from a nontelomeric replication origin that initiates DNA synthesis more proximally in the chromosome arm at an earlier time in S phase.

Alpha satellite DNA sequences indigenous to specific human chromosomes have been cloned $(36,39,41)$. Similarly, candidate sequences for human telomeres, which consist of multiple repeats of the 6-bp TTAGGG sequence, have been isolated by DNA cloning $(2,6,9,28)$. The availability of candidate centromeric and telomeric DNA sequences has allowed us to investigate the timing of their replication by using a retroactive synchrony technique (15) that separates cells in various stages of $S$ phase according to DNA content. Our results indicate that unlike the earlyreplicating centromeric DNA of yeast cells, centromereassociated alpha satellite sequences of human cells are replicated late during $S$ phase and the alpha satellite sequences of different chromosomes replicate at slightly different times. The telomeric repeats of human cells replicate throughout $S$ phase, unlike the previously studied DNA sequences adjacent to some yeast telomeres (26).

\section{MATERIALS AND METHODS}

Cell culture and labeling. The human male lymphoblast line TK6 (obtained from the American Type Culture Collec- 
tion) was grown at $37^{\circ} \mathrm{C}$ in $10 \% \mathrm{CO}_{2}$ in RPMI 1640 medium supplemented with $15 \%$ fetal calf serum (FCS) (GIBCO). Cultures maintained at $2.5 \times 10^{5}$ to $5 \times 10^{5}$ cells per ml were density labeled by incubation for $1 \mathrm{~h}$ with 5-bromo-2'deoxyuridine (BU; $30 \mu \mathrm{g} / \mathrm{ml}$ ) and 5-fluoro-2'-deoxyuridine (FU; $5 \mu \mathrm{g} / \mathrm{ml}$ ). Mouse-human somatic cell hybrid lines containing a normal human $\mathrm{X}$ chromosome $(\mathrm{t} 60-12 ; 3)$ or a translocation onto a mouse chromosome of a human X-chromosome segment that includes the centromere region (t6012aza15b; C. J. Brown, unpublished data) were grown in Dulbecco modified Eagle medium supplemented with $7.5 \%$ FCS. The human X chromosome in t60-12 was maintained under hypoxanthine-aminopterin-thymidine selection. Logarithmically growing hybrid cell lines were labeled for $1 \mathrm{~h}$ with BU and FU in Dulbecco modified Eagle medium plus 7.5\% FCS.

Separation of cells into fractions of the cell cycle and reanalysis. After labeling, cells were fixed in $70 \%$ ethanol and stored at $4^{\circ} \mathrm{C}$. Cells were prepared and analyzed on a Becton Dickinson FACSTAR cell sorter as described previously $(15,16)$ except that $10^{8}$ cells were resuspended in a solution consisting of $10 \mathrm{mg}$ of chromomycin $\mathrm{A}_{3}$ and $0.6 \mathrm{~g}$ of $\mathrm{MgCl}_{2} \cdot 6 \mathrm{H}_{2} \mathrm{O}$ in $200 \mathrm{ml}$ of $\mathrm{H}_{2} \mathrm{O}\left(4^{\circ} \mathrm{C}\right)$. Cells suspended at $10^{7} / \mathrm{ml}$ were sorted at a flow rate of approximately 4,000 cells per $\mathrm{s}$ and were collected in 35 -mm-diameter tissue culture dishes containing $0.5 \mathrm{ml}$ of FCS to facilitate the satisfactory retrieval of cells. To determine the accuracy of sorting, 100 $\mu$ l of sorted cells was added to $150 \mu$ l of the chromomycin $A_{3}$ solution, allowed to sit on ice for at least $15 \mathrm{~min}$, and then reanalyzed on the cell sorter.

Separation of replicated and unreplicated DNA. Cells from each collection dish were transferred to Eppendorf tubes, centrifuged, resuspended in $200 \mu$ l of DNA extraction buffer (1\% sodium dodecyl sulfate, $200 \mathrm{mM}$ Tris chloride [pH 8.0], $100 \mathrm{mM}$ EDTA, $100 \mu \mathrm{g}$ of proteinase $\mathrm{K}$ per $\mathrm{ml}$ ) and incubated at $37^{\circ} \mathrm{C}$ for at least $6 \mathrm{~h}$. Samples were extracted once with phenol, once with phenol-chloroform (1:1, vol/vol), and once with chloroform and were then ethanol precipitated. The DNA samples from experiment III were resuspended in a total of $40 \mu \mathrm{l}$ and digested to completion with Sau3AI restriction endonuclease in standard buffer (New England BioLabs). Experiment III samples were then ethanol precipitated and resuspended in $200 \mu$ l of sterile $\mathrm{H}_{2} \mathrm{O}$. Samples from experiments I, II, IV, and V were resuspended in 200 $\mu l$ of sterile $\mathrm{H}_{2} \mathrm{O}$ and sheared by passage 20 times through a tuberculin syringe. All samples were then added to ultrapure $\mathrm{Cs}_{2} \mathrm{SO}_{4}$ (Bethesda Research Laboratories, Inc.) and loaded into $5.2-\mathrm{ml}$ centrifuge tubes to obtain a final refractive index of 1.3695. Gradients were formed by centrifugation at 30,000 rpm in a VTi80 (Beckman) rotor for at least $60 \mathrm{~h}$ at $19^{\circ} \mathrm{C}$. Then 22 to 25 equal-volume fractions were collected from the bottom of each gradient by using a peristaltic pump.

Hybridization and quantitation. Aliquots of DNA in $\mathrm{Cs}_{2} \mathrm{SO}_{4}$ solution from each fraction of each gradient were denatured with $\mathrm{NaOH}$ and applied to nitrocellulose filters, using a slot blot apparatus as described by Brown et al. (5). DNA fragments containing chromosome-specific alpha satellite sequences were isolated from plasmids carrying them (pBamX7 [41], p17H8 [38], and p7tet [36]) by electrophoresis in low-melting-point agarose (Nusieve) and labeled by the method of random priming directly in the agarose as described by Feinberg and Vogelstein (13) (using $200 \mathrm{ng}$ of DNA in each reaction). Plasmid pHuR93 (28), carrying the telomeric repeat insert, was the kind gift of R. Moyzis; the telomeric segment was isolated on an agarose gel after digestion of plasmid DNA with PstI and was labeled by standard nick translation procedures (23). The entire BLUR8 plasmid, which carries the human Alu repeat, and the entire pCHOR32 plasmid (11), which contains a hamster Alu-like sequence (hybridizable to the mouse equivalent), were also labeled by nick translation. Hybridization to

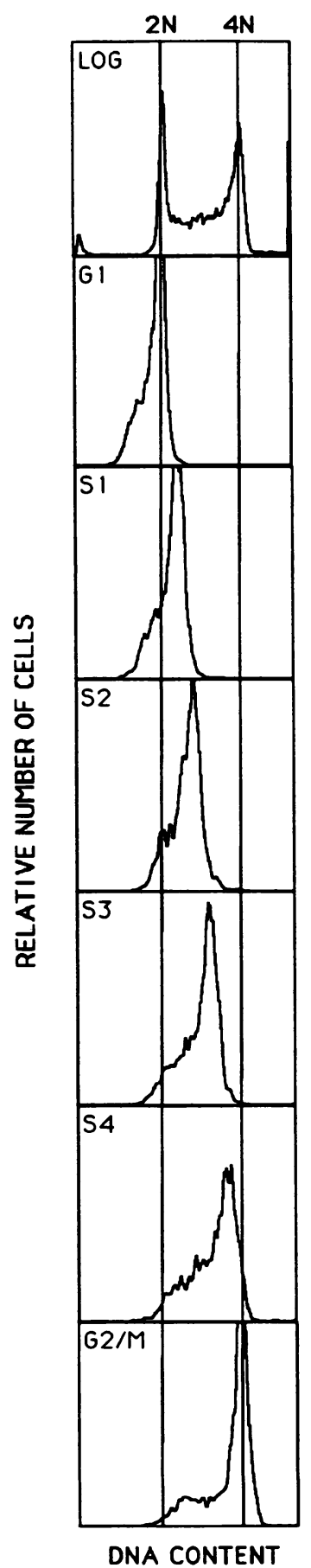

FIG. 1. Fluorescence histograms of fractionated TK6 cells. Logarithmically growing TK6 cells (LOG) were labeled for $1 \mathrm{~h}$ with BU, stained with chromomycin $A_{3}$, and sorted into various fractions of the cell cycle (G1, S1 to $S 4$, and $G 2 / M)$. The relative number of cells is plotted on the ordinate, and the DNA content is plotted on the abscissa. The reanalysis of each sorted population from cell-sorting experiment III is shown. 


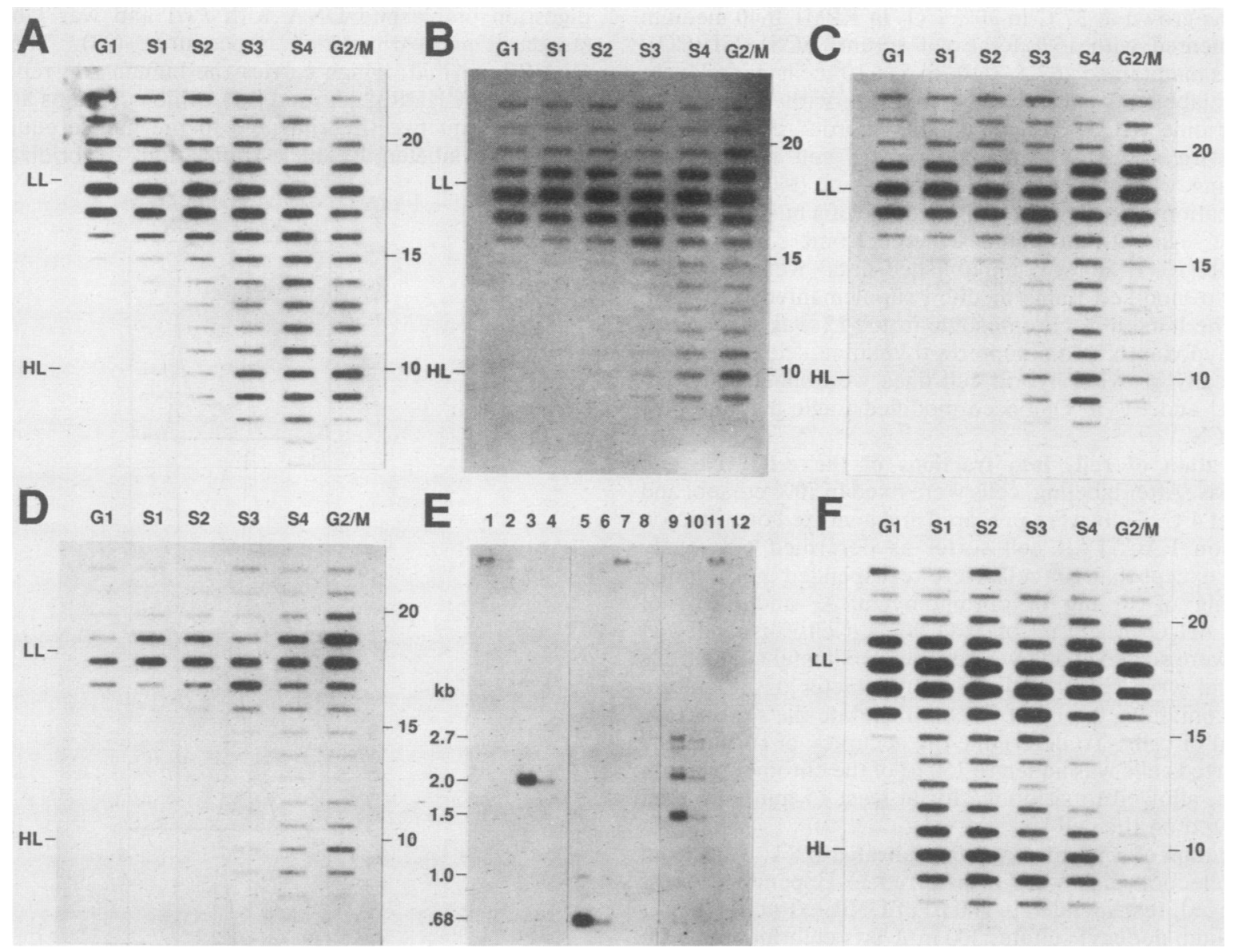

FIG. 2. Time of replication of human alpha satellite sequences. HL and LL DNA was separated by density gradient centrifugation in $\mathrm{Cs}_{2} \mathrm{SO}_{4}$. Twenty-two fractions were collected from the bottom of each gradient and applied to nitrocellulose filters, using a slot blot apparatus. Slot blots from cell-sorting experiment II were hybridized with equal amouints of chromosome 17- and 7-specific probes under low-stringency conditions (A), X-chromosome-specific alpha satellite insert from pBamX7 (B), chromosome 17-specific alpha satellite insert from p17H8 (C), chromosome 7-specific insert from p7tet (D), and BLUR8, which contains the cloned Alu repetitive element (F). The positions of HL and LL DNA are indicated to the left, and cell cycle stage is indicated above each lane. All chromosome-specific alpha satellite probes were checked for chromosome specificity by probing Southern blots of TK6 genomic DNA. (E) Lanes: 1, 5, and 9, $3 \mu \mathrm{g}$ of EcoRI-digested DNA; 2, 6, and 10, $300 \mathrm{ng}$ of EcoRI-digested DNA; 3, 7, and 11, $3 \mu \mathrm{g}$ of BamHI-digested DNA; 4, 8, and 12, $300 \mathrm{ng}$ of BamHI-digested DNA. Lanes 1 to 4 were probed with the pBamX7 insert (41); lanes 5 to 8 were probed with the p7tet insert (36); lanes 9 to 12 were probed with the p17H8 insert (38). Size markers are indicated on the left.

detect chromosome-specific alpha satellite DNA sequences was performed at high stringency as described previously (37). Hybridization to detect all alpha satellite sequences was performed at low stringency at $42^{\circ} \mathrm{C}$ in $3 \times \mathrm{SSC}$ (SSC is $0.15 \mathrm{M} \mathrm{NaCl}$ plus $0.015 \mathrm{M}$ sodium citrate)-50\% formamide$10 \%$ dextran sulfate, with a final wash at $55^{\circ} \mathrm{C}$ in $2 \times \mathrm{SSC}$. Hybridization to detect telomeric sequences was performed at $48^{\circ} \mathrm{C}$ in $3 \times$ SSC $-50 \%$ formamide, with a final wash at $54^{\circ} \mathrm{C}$ in $0.1 \times$ SSC. BLUR8 and pCHOR32 hybridizations were carried out at $68^{\circ} \mathrm{C}$ in $2 \times$ SSC. Quantitation of the amount of heavy-light (HL) and light-light (LL) DNA present in each gradient was performed by using a Helena Laboratories Quick Scan R\&D densitometer.

$B a / 31$ digests and genomic Southern analysis. TK6 genomic DNA was digested for $0,2,5,10,20$, and 40 min with Bal31 (6 U/24 $\mu \mathrm{g}$ of DNA) in standard buffer (NEB), followed by digestion to completion with Sau3AI in standard buffer (NEB). Each time point was divided in half and run in duplicate on a $0.7 \%$ agarose gel at approximately $1.5 \mathrm{~V} / \mathrm{cm}$; transfer to nitrocellulose filters was performed as described previously (23). One half of this duplicate blot was hybrid- ized with the pHuR93 insert at $48^{\circ} \mathrm{C}$ in $3 \times \mathrm{SSC}-50 \%$ formamide, with a final wash at $54^{\circ} \mathrm{C}$ in $0.1 \times \mathrm{SSC}$, while the other half was hybridized with BLUR8. Genomic Southern blots of TK6 DNA digested with restriction endonuclease EcoRI or BamHI were performed in triplicate. Each blot was hybridized with the plasmid insert of either pBamX7, p7tet, or p17H8 under previously described conditions (37).

In situ hybridization. Coincidence of the site of alpha satellite localization and the primary constriction in t60-12 and t60-12aza15b cells was evaluated by fluorescence in situ hybridization to metaphase chromosomes, using biotin-labeled $\mathrm{pBamX} 7$ as described previously (17) and a commercially available chromosome in situ hybridization kit (Oncor, Inc., Gaithersburg, Md.).

\section{RESULTS}

Timing of replication of alpha satellite DNA sequences. Cytogenetic analysis after pulse-labeling has suggested that the DNA sequences associated with centromeric regions of eucaryotic chromosomes from higher organisms replicate 
concurrently and late in $S$ phase $(7,10,22,27,33,34)$. However, the limited sensitivity of cytological methods has precluded resolution of possible differences in the timing of DNA replication from the multiple origins that are presumed to be present in the long chromosomal DNA segments comprising the alpha satellite sequences or differences in the replication time of alpha satellite sequences located on different chromosomes. To determine the extent of concurrence of replication timing of the multiple repeats of alpha satellite DNA sequences, we analyzed cells that had been synchronized in the cell cycle retroactively by fluorescenceactivated sorting according to the DNA content of nuclei. Human male TK6 cells growing in tissue culture were labeled for $1 \mathrm{~h}$ with BU, stained with the DNA-specific dye chromomycin, and sorted as described previously (15). In experiments I, II, and III, which represent separate cellsorting experiments, approximately $2 \times 10^{5}$ TK6 cells were collected according to DNA content into six fractions that represent cell populations in four separate stages of $S$ phase (S1 through S4) and in the $\mathrm{G} 1$ and $\mathrm{G} 2 / \mathrm{M}$ phases of the cell cycle. The reanalysis of a typical TK6 sorting experiment is shown in Fig. 1. DNA from fractionated cells in experiments I and II was sheared by passage through a needle, while DNA from experiment III was digested to completion with Sau3AI before being loaded on density gradients. BUsubstituted HL DNA was separated from unsubstituted (i.e., unreplicated) LL DNA on $\mathrm{Cs}_{2} \mathrm{SO}_{4}$ gradients. DNA obtained from fractionated gradients was immobilized in a slot pattern on nitrocellulose membranes and then probed with a mixture containing equal amounts of ${ }^{32} \mathrm{P}$-labeled alpha satellite DNA sequences from chromosomes 17 and 7 (i.e., the inserts from plasmids p17H8 and p7tet); previous experiments have shown that this mixture detects alpha satellite DNA sequences on all human chromosomes cytologically when hybridization is carried out under low-stringency conditions that permit significant sequence mismatch $(37,40 a)$. Each lane of the slot blots in Fig. 2 represents fractions from a single gradient, and all slot blots shown in Fig. 2 are from cell-sorting experiment II. Significant amounts of replicated (i.e., HL) alpha satellite-hybridizable DNA sequences did not appear until S2, increasing in the later S-phase fractions and the G2/M fraction (Fig. 2A). The amount of replicated alpha satellite DNA sequences in multiple cell cycle fractions (S2 to $\mathrm{G} 2 / \mathrm{M}$ ) suggests that the timing of replication of the DNA sequences hybridizing under low-stringency conditions with the mixed probe varies either within individual megabase clusters of alpha satellite DNA or from chromosome to chromosome.

To investigate possible individual differences in the timing of replication of alpha satellite sequences on different chromosomes, probes representing cloned alpha satellite DNA sequences from the $\mathrm{X}$ chromosome and from chromosomes 17 and 7 were used individually under stringent hybridization conditions to analyze slot blot filters containing DNA isolated from cells sorted according to DNA content as described above. Replication of DNA sequences hybridizing with the X-chromosome-specific alpha satellite DNA probe occurred at the very end of S phase (Fig. 2B). HL DNA was restricted almost entirely to the $S 4$ and $G 2 / M$ fractions; although a small percentage of the HL DNA was present in the S3 fraction, no significant density-labeled replicated DNA was observed in the $\mathrm{G} 1, \mathrm{~S} 1$, or $\mathrm{S} 2$ fractions. These data indicate that the majority of the alpha satellite sequences on the single (and therefore active) $\mathrm{X}$ chromosome in male TK6 cells replicate at the very end of $S$ phase. Figure 2C shows another slot blot containing fractions from the
TABLE 1. Replication time of alpha satellite and telomeric repeats

\begin{tabular}{|c|c|c|c|c|c|c|c|c|}
\hline \multirow{2}{*}{ Expt } & \multirow{2}{*}{ Cell line } & \multirow{2}{*}{$\begin{array}{l}\text { Repetitive } \\
\text { element }\end{array}$} & \multicolumn{6}{|c|}{ Relative amt of replication ${ }^{a}$} \\
\hline & & & G1 & S1 & S2 & S3 & S4 & G2/M \\
\hline \multirow[t]{5}{*}{ I } & TK6 & Mixed satellite & 0 & 0 & 13 & 21 & 21 & 13 \\
\hline & & X satellite & 0 & 0 & 2 & 14 & 17 & 11 \\
\hline & & 17 satellite & 0 & $\mathbf{0}$ & 14 & 22 & 15 & 6 \\
\hline & & 7 satellite & $\mathbf{0}$ & 0 & 7 & 20 & 17 & 16 \\
\hline & & Alu & 0 & 17 & 10 & 10 & 4 & 3 \\
\hline \multirow[t]{5}{*}{ II } & TK6 & Mixed satellite & 0 & 0 & 9 & 24 & 35 & 41 \\
\hline & & $\mathrm{X}$ satellite & 0 & 0 & 0 & 7 & 16 & 18 \\
\hline & & 17 satellite & 0 & 0 & 0 & 18 & 29 & 8 \\
\hline & & 7 satellite & 0 & 0 & 0 & 10 & 21 & 7 \\
\hline & & Alu & 0 & 21 & 19 & 12 & 8 & 2 \\
\hline \multirow[t]{6}{*}{ III } & TK6 & Mixed satellite & 0 & 9 & 23 & 44 & 59 & 30 \\
\hline & & X satellite & 0 & 0 & 8 & 17 & 36 & 17 \\
\hline & & 17 satellite & $\mathbf{0}$ & 8 & 16 & 34 & 35 & 5 \\
\hline & & 7 satellite & 0 & 0 & 9 & 22 & 34 & 15 \\
\hline & & Alu & 5 & 42 & 29 & 22 & 15 & 12 \\
\hline & & Telomere & 0 & 16 & 23 & 19 & 16 & 5 \\
\hline \multirow[t]{2}{*}{ IV } & t60-12 & $\mathrm{X}$ satellite & 0 & 0 & 6 & 10 & 11 & 11 \\
\hline & & Alu-like & 2 & 11 & 9 & 8 & 5 & 4 \\
\hline \multirow[t]{2}{*}{ V } & t60-12aza15b & $\mathrm{X}$ satellite & 0 & 0 & 2 & 8 & 9 & 8 \\
\hline & & Alu-like & 0 & 22 & 19 & 11 & 9 & 8 \\
\hline
\end{tabular}

${ }^{a}$ Data for alpha satellite, telomere, Alu, and Alu-like repeats in which four section of $S$ phase were sorted. Experiments I, II, and III represent separate cell sortings of TK6 cells. In experiments I, II, IV, and V, DNA was sheared before gradient centrifugation. In experiment III, DNA was digested with Sau3AI before gradient centrifugation. Numbers represent densitometric quantitation of the relative amount of replication $(\mathrm{HL} / \mathrm{HL}+\mathrm{LL})$ during each cell cycle interval.

same cell-sorting experiment and probed with ${ }^{32} \mathrm{P}$-labeled chromosome 17-specific alpha satellite probe (i.e., the insert from p17H8). In this experiment, the majority of replicated DNA was found in the S4 fraction, with less in the S3 fraction and even less in the $\mathrm{G} 2 / \mathrm{M}$ fraction. No detectable HL DNA was observed in the G1, S1, or S2 fractions. Thus, while the alpha satellite DNA sequences specific to chromosome 17 also replicated late during the cell cycle, these sequences appeared to replicate slightly earlier than did the alpha satellite sequences of the $\mathrm{X}$ chromosome. Analogous experiments using the probe from p7tet (Fig. 2D) indicate that the alpha satellite sequences of chromosome 7 show a replication time intermediate to that observed for alpha satellite sequences of chromosomes $X$ and 17 . The data for alpha satellite replication time for three separate TK6 cell sorting experiments are summarized in Table 1. Each chromosome-specific alpha satellite probe was checked for specificity by hybridization to Southern blots of TK6 genomic DNA (Fig. 2E) as described previously (pEamX7 [41]; p17H8 [38]; p7tet [36]).

To ensure that the results described above were not a consequence of labeling artifacts or other anomalies that might cause unequal representation of HL DNA in S-phase fractions obtained on the cell sorter, slot blots from each TK6 cell-sorting experiment were subsequently probed with a ${ }^{32}$ P-labeled DNA of cloned human Alu repeats whose homologs in other species have been shown previously to replicate throughout $S$ phase (15). HL DNA hybridizing to the Alu probe was found to be present in all S-phase fractions, with a slight skewing to early $S$ phase, as has been shown previously for other cell lines (15) (Fig. 2F and Table 1). Alu-hybridizing HL DNA was seen also in the G2/M fraction, presumably as a result of the presence in this fraction of cells that were in $S$ phase during the early part of the 1-h BU pulse but had finished replication and moved on 

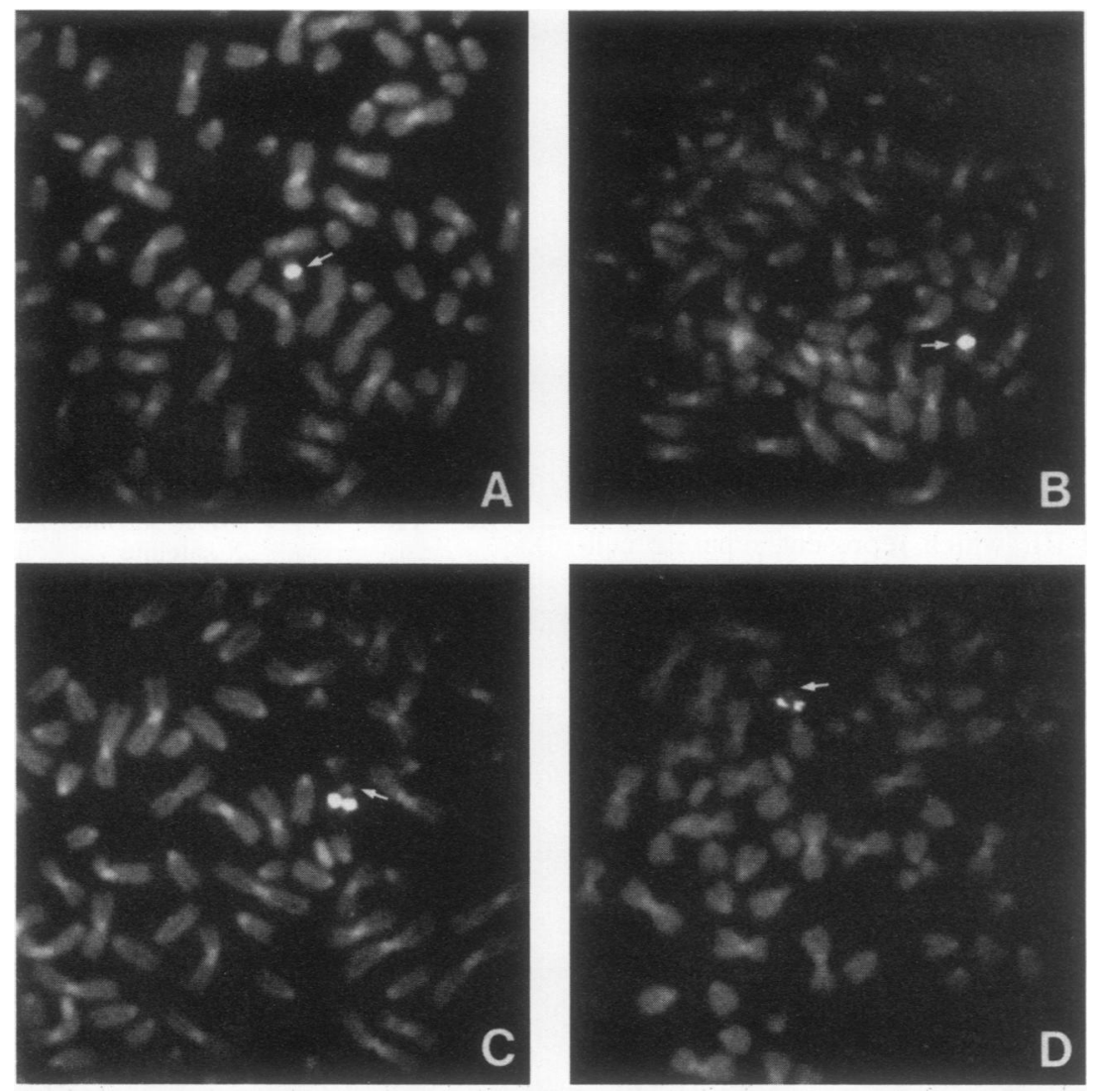

FIG. 3. Localization of X-chromosome alpha satellite DNA by fluorescence in situ hybridization. Metaphase chromosomes were prepared from t60-12 (A and B) and t60-12aza15b (C and D) cells and hybridized to biotin-labeled pBamX7. Sites of hybridization were detected with fluorescein-conjugated avidin and photographed with Kodak 100HC color slide film, using a Leitz Diaplan photomicroscope. Black-and-white prints were made from the original color slide. Arrows indicate the primary constrictions associated with the centromere of the human $X$ chromosome (in A and B) or with the centromere of the mouse-human translocation chromosome (C and D). Alpha satellite sequences do not localize to the position of the primary constriction in t60-12aza15b cells, as indicated by the clear absence of sister chromatid association at the alpha satellite signal.

to the G2/M stage of the cell cycle by the end of the labeling period.

Timing of replication of human alpha satellite sequences in mouse-human hybrid cell lines. To determine whether human $\mathrm{X}$-chromosome alpha satellite sequences retain their characteristic timing of replication when the associated centromere is nonfunctional, we examined the timing of $\mathrm{X}$-chromosome replication in two related mouse-human hybrid cell lines; one cell line, t60-12, contains an intact active human $X$ chromosome, while the second cell line, t60-12aza15b (a derivative of $160-12$ ), contains a portion of the human $X$ chromosome and its entire alpha satellite array translocated onto a mouse chromosome. In t60-12 cells, the intact human $\mathrm{X}$ chromosome uses its own centromere for segregation (3); $\mathrm{X}$-chromosome alpha satellite sequences are confined to the region of the primary constriction in all cells (Fig. 3A and B). In cell line t60-12aza15b, in contrast, the human chromosomal DNA segment carrying alpha satellite sequences is no longer in the region of the primary constriction (Fig. $3 \mathrm{C}$ and D), and the translocated human DNA is efficiently segregated by the mouse centromere. The reanalysis of the cell sorting of each cell line is shown in Fig. 4. Slot blots of DNA obtained in cell-sorting experiments of both cell lines and probed with the $\mathrm{X}$-chromosome-specific alpha satellite probe showed that both the normally located and translocated alpha satellite sequences replicated similarly late during the cell cycle, principally during S3, S4, and G2, with little or no replication detectable in the $\mathrm{G} 1, \mathrm{~S} 1$, and $\mathrm{S} 2$ fractions (Fig. 5 and Table 1). To ensure that HL DNA was present in all S-phase fractions, slot blots from both cell-sorting experiments IV and V were also probed with pCHOR32, which contains the hamster Alu-like sequence. HL DNA hybridizing to pCHOR32 was detected in all S-phase fractions (Table 1).

Timing of replication of telomeric repeats. To address the question of when human telomeric sequences replicate, DNA from cell-sorting experiment III was digested to completion with Sau3AI and subsequently run on a $\mathrm{Cs}_{2} \mathrm{SO}_{4}$ gradient. Sau3AI digestion removes much of the flanking chromosomal DNA from the telomeric ends; upon probing Sau3AI-digested TK6 genomic DNA with the pHuR93 insert, telomeric fragments of less than $9 \mathrm{~kb}$ (Fig. 6B) were detected. When slot blots from this cell-sorting experiment were hybridized with the insert from pHuR93, HL DNA was detected in all four S-phase fractions (Fig. 6A and Table 1). The probe and hybridization conditions used in these experiments were checked for telomeric specificity by performing Bal31 digests of TK6 genomic DNA for various amounts of time (29; see Materials and Methods). Duplicate blots of these digests were hybridized with either the pHuR93 insert (Fig. 6B), which detects only Bal31-sensitive fragments, or the BLUR 8 plasmid (Fig. 6C), which detects chromosome- 


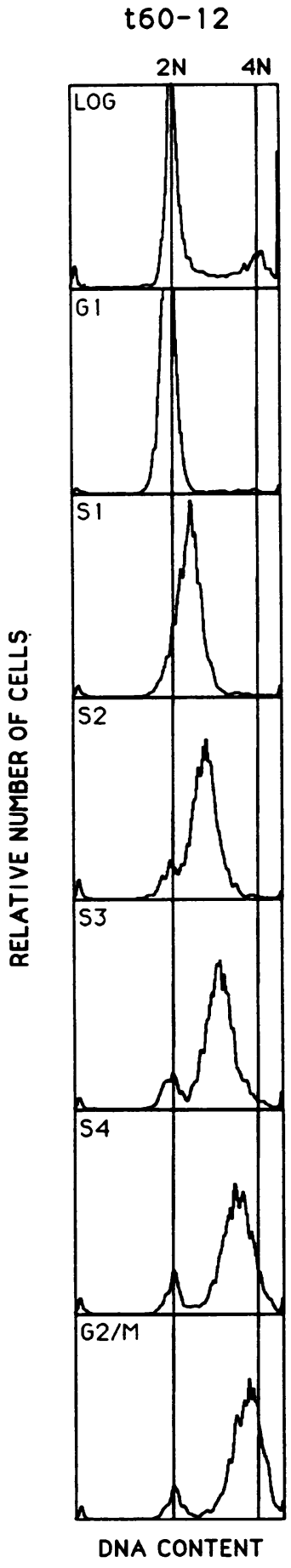

t60-12aza15b

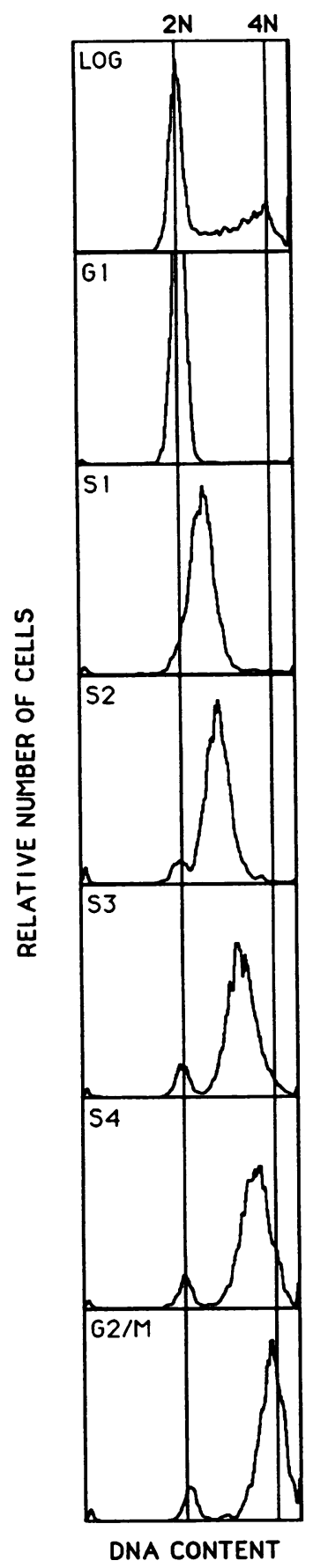

FIG. 4. Fluorescence histograms of fractionated mouse-human somatic hybrid cell lines. Logarithmically growing t60-12 (containing the intact $X$ chromosome) and t60-12aza15b (containing the translocated $X$ chromosome) cells (LOG) were labeled with BU for $1 \mathrm{~h}$ and stained for DNA content with chromomycin $\mathrm{A}_{3}$. Each cell line was then fractionated on the basis of DNA content (G1, S1 to S4, G2/M). The relative number of cells is plotted on the ordinate, and the DNA content is plotted on the abscissa. Reanalysis of the resulting fractionations from experiments IV (t60-12) and V (t6012aza15b) are shown. internal fragments that are much less accessible to the exonucleolytic activity of $\mathrm{Bal} 31$.

\section{DISCUSSION}

The results reported here indicate that the DNA sequences associated with human centromeres and telomeres differ in their timing of replication during $S$ phase of the cell cycle. All of the alpha satellite sequences associated with human centromeres replicated during the latter half of $S$ phase, while telomeric DNA replicated throughout $S$ phase. The highly specific timing of replication of alpha satellite sequences suggests not only that they contain origins of replication but also that the multiple origins that necessarily are present within the lengthy alpha satellite repeats of a single chromosome (estimated at 1 to $5 \mathrm{Mb} ; 40$ ) and within the alpha satellite repeats of different chromosomes are programmed to initiate replication at approximately the same time, enabling the largely synchronous replication of many thousands of kilobases of DNA. This pattern of replication timing differs from that observed for certain other repetitive sequences, such as Alu, which share no common timing of replication and replicate throughout $S$ phase. The timing of replication of human alpha satellite sequences in late $\mathrm{S}$ phase also contrasts with the early-S-phase replication timing observed for the centromeres of yeast cells (26).

Although the alpha satellite sequences of human chromosomes $\mathrm{X}$ and 17 are both replicated late during $\mathrm{S}$ phase, the percentage of each alpha satellite segment replicating during a given interval in $S$ phase varied between the two chromosomes in a reproducible fashion. Chromosome $\mathrm{X}$-specific alpha satellite DNA replicated slightly later than the alpha satellite DNA of chromosome 17, which shares approximately 70 to $85 \%$ alpha satellite sequence homology with chromosome $X(38)$ and is in the same subset grouping (39). As the cells studied were obtained from males, the later timing of replication of X-chromosome DNA cannot be attributed to $\mathrm{X}$-chromosome inactivation, which previously has been shown to result in late replication $(14,18)$.

Translocation of human X-chromosome alpha satellite DNA sequences onto a mouse chromosome did not alter their timing of replication, as determined by density gradient analysis. This result is in agreement with earlier cytological experiments in which translocated chromosomal segments maintained their characteristic replication banding patterns (32). Our findings demonstrate that the late replication timing of human X-chromosome alpha satellite DNA is retained when the centromeric locus associated with this DNA does not function as a centromere.

In contrast to human alpha satellite DNA sequences, the human telomeric repeats that we studied replicated throughout $\mathrm{S}$ phase. Because the experimental protocol used does not distinguish the replication of individual telomeres, a number of possible explanations could account for our findings. In principle, telomeric replication could be a stochastic process in which the time of replication of each telomere varies from one cell cycle to the next. If, on the other hand, the timing of telomere replication is similar in different cells and different cell cycles, our results suggest either that there is a specific interval in S phase during which each telomeric repeat replicates and this specific interval differs from one telomeric repeat to the next or, alternatively, that the replication of each individual telomeric repeat extends throughout $S$ phase. If the replication rate of human telomeres is similar to that measured for other human chromosomal DNA sequences (1.7 to $1.9 \mathrm{~kb} / \mathrm{min}$; 4$)$, and 


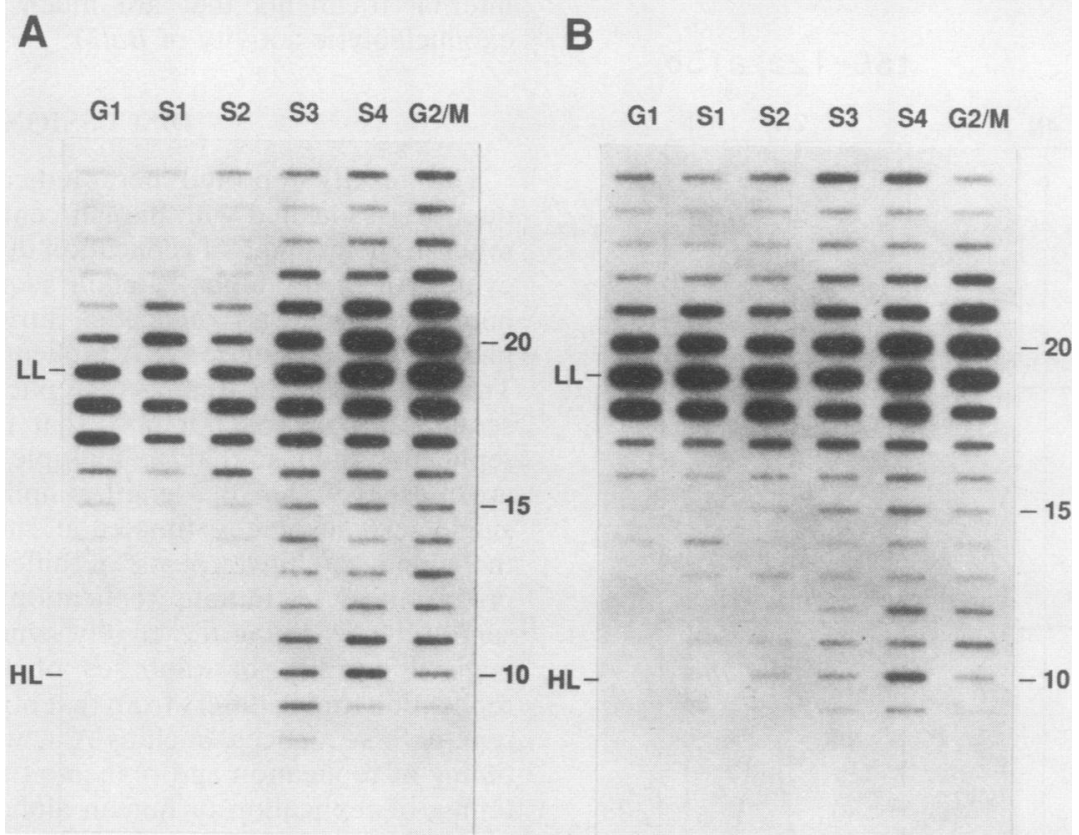

FIG. 5. Time of replication of X-chromosome alpha satellite sequences in mouse-human somatic hybrid cell lines. The hybrid cell lines were sorted and blotted as described previously. Each blot was probed with the X-chromosome-specific alpha satellite insert from pBamX7. The positions of HL and LL DNA are indicated to the left, and the cell cycle stage is indicated above each lane. (A) t60-12 cell line (containing the intact human $\mathrm{X}$ chromosome). (B) t60-12aza15b cell line (containing the X-chromosome translocation).

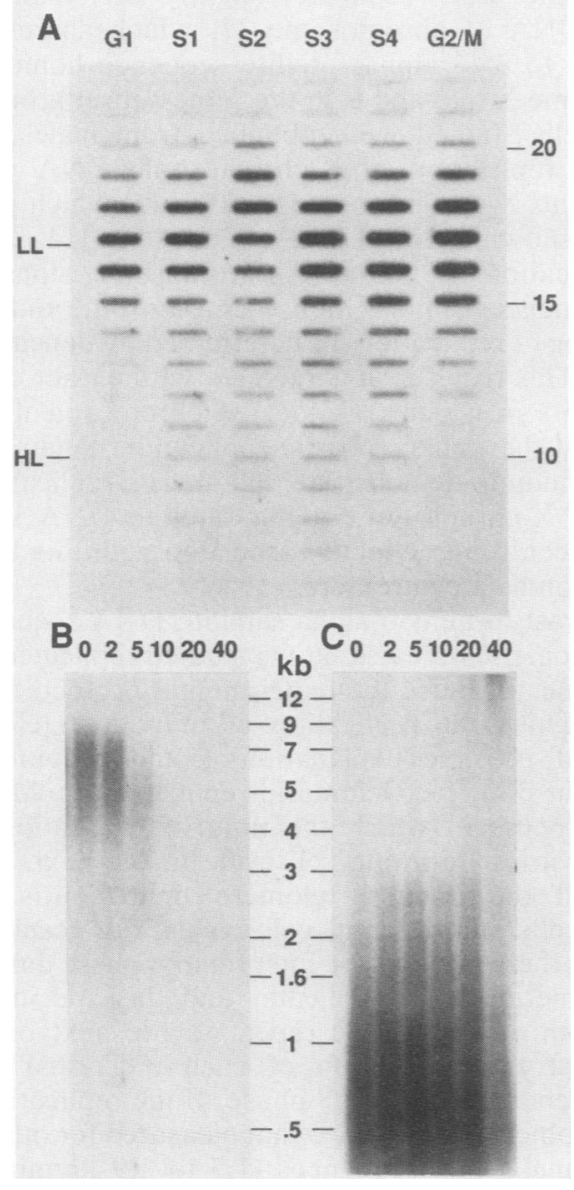

taking into account the length of telomeric repeats in TK6 cells $(<9 \mathrm{~kb}$; Fig. 6B), the latter explanation seems less likely. Rather, each individual telomere may have a characteristic time of replication conferred upon it either by a proterminal origin in the adjacent chromosomal DNA or by a telomeric origin, which may initiate replication at different times from one telomere to the next; the collective effects of either mechanism would be the replication of telomeric DNA throughout $\mathrm{S}$ phase. Replication from a proterminal chromosomal origin appears to be the case for a telomere on chromosome III in the yeast Saccharomyces cerevisiae, in which initiation of replication occurs $40 \mathrm{~kb}$ away from the telomere at the $\mathrm{A6C}$ autonomously replicating sequence element and proceeds to the telomere before terminating (J. A. Huberman et al., Abstr. Meet. Euk. DNA Replic. 1989, p. 79), Although the results that we obtained for the replication of human telomeric DNA are different from those reported for yeast cells (22), the timing of replication of the actual yeast telomere sequences was not examined. Also, as many yeast chromosomes lack the telomere-adjacent repetitive sequences examined in those studies (20), it still remains possible that yeast telomere sequences themselves or yeast telomeres lacking this adjacent repetitive element could replicate at other times in S phase.

FIG. 6. Time of replication of telomeric repetitive sequences. A slot blot from experiment III was hybridized with the human telomeric DNA insert isolated from pHUR93 (A). The positions of HL and LL DNA are indicated to the left, and cell cycle stage is indicated above each lane. Duplicate blots of TK6 genomic DNA (B and $\mathrm{C}$ ) digested with $\mathrm{Ba} 31$ for various amounts of time and subsequently digested with Sau3AI were probed with the pHuR93 insert at $48^{\circ} \mathrm{C}$ in $3 \times \mathrm{SSC}-50 \%$ formamide (B) or BLUR 8 (C). Bal31 digestion times are indicated above each lane in minutes. Size markers are indicated in the center. 


\section{ACKNOWLEDGMENTS}

We thank C. J. Brown for providing hybrid cells and V. E. Powers for performing the in situ hybridization experiments.

This study was supported by Public Health Service grants HG 00325 to S.N.C. and HG 00107 , both from the National Institutes of Health, and March of Dimes grant 1-1178 to H.F.W. K.G.T.H. and D.M.G. were supported by Public Health Service predoctoral training grant GM 07790 from the National Institutes of Health.

\section{LITERATURE CITED}

1. Adegoke, J. A., and J. H. Taylor. 1977. Sequence programming of DNA replication over the $S$ phase of Chinese hamster cells. Exp. Cell Res. 104:47-54.

2. Allshire, R. C., J. R. Gosden, S. H. Cross, G. Cranston, D. Rout, N. Sugawara, J. W. Szostak, P. A. Fantes, and N. D. Hastie. 1988. Telomeric repeat of $T$. thermophila cross hybridizes with human telomeres. Nature (London) 332:656-659.

3. Brown, C. J., V. E. Powers, D. L. Munroe, R. Sheinin, and H. F. Willard. 1989. Gene on short arm of human X chromosome complements murine tsA1S9 DNA synthesis mutation. Somatic Cell Mol. Genet. 15:173-178.

4. Brown, E. H., M. A. Iqbal, S. Stuart, K. S. Hatton, J. Valinsky, and C. L. Schildkraut. 1987. Rate of replication of the murine immunoglobulin heavy-chain locus: evidence that the region is part of a single replicon. Mol. Cell. Biol. 7:450-457.

5. Brown, P. C., T. D. Tlsty, and R. T. Schimke. 1983. Enhancement of methotrexate resistance and dihydrofolate reductase gene amplification by treatment of mouse 3T6 cells with hydroxyurea. Mol. Cell. Biol. 3:1097-1107.

6. Brown, W. R. A. 1989. Molecular cloning of human telomeres in yeast. Nature (London) 338:774-778.

7. Camargo, M., and J. Cervenka. 1982. Patterns of DNA replication of human chromosomes. II. Replication map and replication model. Am. J. Hum. Genet. 34:757-780.

8. Clark, L., and J. Carbon. 1985. The structure and function of yeast centromeres. Annu. Rev. Genet. 19:29-56.

9. Cross, S. H., R. C. Allshire, S. J. McKay, N. I. McGill, and H. J. Cooke. 1989. Cloning of human telomeres by complementation in yeast. Nature (London) 338:771-774.

10. Crossen, P. E., S. Pathak, and F. E. Arrighi. 1975. A high resolution study of the DNA replication patterns of Chinese hamster chromosomes using sister chromatid differential staining technique. Chromosoma 52:339-347.

11. Crouse, G. F., C. C. Simonsen, R. N. McEwan, and R. T. Schimke. 1982. Structure of amplified normal and variant dihydrofolate reductase genes in mouse sarcoma S180 cells. J. Biol. Chem. 257:7887-7897.

12. DuPraw, E. J. 1965. Macromolecular organization of nuclei and chromosomes: a folded fibre model based on whole-mount electron microscopy. Nature (London) 206:338-343.

13. Feinberg, A. P., and B. Vogelstein. 1984. Addendum. A technique for radiolabeling DNA restriction endonuclease fragments to high specific activity. Anal. Biochem. 137:266-267.

14. German, J. 1962. DNA synthesis in human chromosomes. Trans. N.Y. Acad. Sci. 24:395-407.

15. Gilbert, D. M., and S. N. Cohen. 1987. Bovine papilloma virus plasmids replicate randomly in mouse fibroblasts throughout $S$ phase of the cell cycle. Cell 50:59-68.

16. Gray, J. W., and P. Coffino. 1979. Cell cycle analysis by flow cytometry. Methods Enzymol. 58:233-248.

17. Greig, G. M., S. B. England, H. M. Bedford, and H. F. Willard. 1989. Chromosome-specific alpha satellite DNA from the centromere of human chromosome 6. Am. J. Hum. Genet. 45:862-872.

18. Grumbach, M. M., A. Morishima, and J. H. Taylor. 1963. Human sex chromosome abnormalities in relation to DNA replication and heterochromatinization. Proc. Natl. Acad. Sci. USA 49:581-589.

19. Hand, R. 1978. Eucaryotic DNA: organization of the genome for replication. Cell 15:317-325.

20. Jager, D., and P. Philippsen. 1989. Many yeast chromosomes lack the telomere-specific $\mathrm{Y}^{\prime}$ sequence. Mol. Cell. Biol. 9:5754-5757.

21. Laskey, R. A., and R. M. Harland. 1981. Replication origins in the eucaryotic chromosome. Cell 24:283-284.
22. Lima-de-Faria, A., and H. Jaworska. 1968. Late DNA synthesis in heterochromatin. Nature (London) 217:138-142.

23. Maniatis, T., E. F. Fritsch, and J. Sambrook. 1982. Molecular cloning: a laboratory manual. Cold Spring Harbor Laboratory, Cold Spring Harbor, N.Y.

24. Masumoto, H., H. Masukata, Y. Muro, N. Nozaki, and T. Okazaki. 1989. A human centromere antigen (CENP-B) interacts with a short specific sequence in alphoid DNA, a human centromeric satellite. J. Cell Biol. 109:1963-1973.

25. Masumoto, H., K. Sugimoto, and T. Okazaki. 1989. Alphoid satellite DNA is tightly associated with centromere antigens in human chromosomes throughout the cell cycle. Exp. Cell Res. 181:181-196.

26. McCarroll, R. M., and W. L. Fangman. 1988. Time of replication of yeast centromeres and telomeres. Cell 54:505-513.

27. Meer, B., H. Hameister, and M. Cerrillo. 1981. Early and late replication patterns of increased resolution in human lymphocyte chromosomes. Chromosoma 82:315-319.

28. Moyzis, R. K., J. M. Buckingham, L. S. Cram, M. Dani, L. L. Deaven, M. D. Jones, J. Meyne, R. L. Ratlifi, and J. Wu. 1988. A highly conserved repetitive DNA sequence, (TTAGGG)n, present at the telomeres of human chromosomes. Proc. Natl. Acad. Sci. USA 85:6622-6626.

29. Mueller, G. C., and K. Kajiwara. 1966. Early-and late-replicating deoxyribonucleic acid complexes in HeLa nuclei. Biochim. Biophys. Acta 114:108-115.

30. Murray, A. W., and J. W. Szostak. 1985. Chromosome segregation in mitosis and meiosis. Annu. Rev. Cell Biol. 1:289-315.

31. Pluta, A. F., C. A. Cooke, and W. C. Earnshaw. 1990. Structure of the human centromere at metaphase. Trends Biochem. Sci. 15:181-185.

32. Stubblefield, E. 1966. Mammalian chromosomes in vitro. XIX. Chromosomes of Don-C, a Chinese hamster fibroblast strain with a part of autosome $1 \mathrm{~b}$ translocated to the $\mathrm{Y}$ chromosome. J. Natl. Cancer Inst. 37:799-817.

33. Stubblefield, E. 1975. Analysis of the replication pattern of Chinese hamster chromosomes using 5-bromodeoxyuridine suppression of 33258 Hoechst fluorescence. Chromosoma 53:209-221.

34. Taylor, J. H. 1960. Asynchronous duplication of chromosomes in cultured cells of Chinese hamster. J. Biophys. Biochem. Cytol. 7:455-464.

35. Tschumper, G., and J. Carbon. 1983. Copy number control by a yeast centromere. Gene 23:221-232.

36. Waye, J. S., S. B. England, and H. F. Willard. 1987. Genomic organization of alpha satellite DNA on human chromosome 7: evidence for two distinct alphoid domains on a single chromosome. Mol. Cell. Biol. 7:349-356.

37. Waye, J. S., A. R. Mitchell, and H. F. Willard. 1988. Organization and genomic distribution of " $82 \mathrm{H}$ " alpha satellite DNA. Human Genet. 78:27-32.

38. Waye, J. S., and H. F. Willard. 1986. Structure, organization, and sequence of alpha satellite DNA from human chromosome 17: evidence for evolution by unequal crossing-over and an ancestral pentamer repeat shared with the human $\mathrm{X}$ chromosome. Mol. Cell. Biol. 6:3156-3165.

39. Waye, J. S., and H. F. Willard. 1987. Nucleotide sequence heterogeneity of alpha satellite repetitive DNA: a survey of alphoid sequences from different human chromosomes. Nucleic Acids Res. 15:7549-7569.

40. Wevrick, R., and H. F. Willard. 1989. Long-range organization of tandem arrays of alpha satellite DNA at the centromeres of human chromosomes: high-frequency array-length polymorphism and meiotic stability. Proc. Natl. Acad. Sci. USA 86:9394-9398.

40a. Willard, H. F. 1990 . Molecular cytogenetics of centromeres of human chromosomes. Chromosomes Today 10:47-60.

41. Willard, H. F., K. D. Smith, and J. Sutherland. 1983. Isolation and characterization of a major tandem repeat family from the human X chromosome. Nucleic Acids Res. 11:2017-2033.

42. Willard, H. F., and J. S. Waye. 1987. Hierarchical order in chromosome-specific human alpha satellite DNA. Trends Genet. 3:192-198.

43. Zakian, V. A. 1989. Structure and function of telomeres. Annu. Rev. Genet. 23:579-604. 